\title{
A represión fascista do profesorado galeguista
}

\author{
(Fascist repression of Galicianist teachers)
}

\author{
Narciso DE GABRIEL \\ Universidade da Coruña
}

\author{
Ao meu amigo Antón Costa Rico, \\ no ano da súa xubilación
}

\begin{abstract}
RESUMO: A represión franquista do profesorado adoptou diversas modalidades, entre elas o asasinato, a depuración profesional e a aplicación da Lei de responsabilidades políticas (1939). Esta represión tamén afectou ao galeguismo, do que trata este traballo. Prestarase especial atención aos mestres mortos e depurados na provincia da Coruña, aínda que tamén se fará referencia ao profesorado de ensino secundario e a outras provincias. $O$ texto remata co proceso a que foi sometido o grupo galeguista de Ferrol (Horacio Fernández Gómez, Ricardo Carvalho Calero e Gonzalo Torrente Ballester, entre outros) por parte do Tribunal Rexional de Responsabilidades Políticas.
\end{abstract}

PALABRAS CHAVE: represión franquista; profesorado; galeguismo; Rafael Fernández Casas; Ramón Otero Pedrayo; Xesús Ferro Couselo.

ABSTRACT: The Francoist repression of teachers took numerous forms, including murder, professional purges and other forms of reprisal covered by the 1939 Political Responsibilities Act (LRP). This repression also extended to the supporters of Galicianism. This article focuses on the killing and purging of primary school teachers in the province of A Coruña. The study concludes with an account of the trial to which to the Ferrol Galicianists Horacio Fernández Gómez, Ricardo Carbalho Calero and Gonzalo Torrente Ballester, among others, were subjected by the Regional Court of Political Responsibilities.

KEYWORDS: Francoist repression; teachers; Galicianism; Rafael Fernández Casas; Ramón Otero Pedrayo; Xesús Ferro Couselo.

Aínda que o Partido Galeguista data de 1931, o sentimento e a mobilización política galeguista tiñan a esa altura una tradición relativamente longa, en cuxo curso Galicia deixou de ser ollada como unha provincia para comezar a ser percibida como unha nación, segundo nos ensinaron Justo Beramendi e outros historiadores. ${ }^{1} \mathrm{E}$ o profesorado tivo un

${ }_{1}^{1}$ Justo Beramendi, De provincia a nación. Historia do galeguismo político (Vigo: Xerais, 2007). 
importante protagonismo neste movemento galeguizador, como nos ensinou, entre outros, o profesor Antón Costa. ${ }^{2}$

A análise da composición socio-profesional do Partido Galeguista realizada por Beramendi amosa que en 1932 o maxisterio representaba o 8,6\% dos 756 afiliados computados, o profesorado de ensino medio o $3 \%$ e o profesorado universitario o $0,3 \%$, cifras que catro anos máis tarde, cando os afiliados sumaban 3.853, se reduciran a 5,1, 0,7 e 0,1 , respectivamente. Na primeira destas datas, o peso do maxisterio só era superado polos empregados e pequenos comerciantes, cada un dos cales rexistraba un $9,7 \%$, e na segunda, por estas mesmas categorías, cuxa porcentaxe diminuíra, os labregos $(28,7 \%)$, os artesáns e autónomos (10,9\%) e os estudantes de ensino medio $(6,1 \%){ }^{3}$ Nunha investigación previa, obra do meu amigo Xavier Castro, tamén destacan os mestres entre os militantes cuxa profesión era coñecida: 31 de 213, ou o que é o mesmo, case o 15\%, aínda que 0 autor se resiste a tirar porcentaxes por ser consciente das limitacións da mostra con que traballa. ${ }^{4}$

Pois ben, o profesorado galeguista sufriu con contundencia a represión fascista, dado que un dos principais obxectivos dos sublevados era erradicar os nacionalismos subestatais. Unha represión que asumiu diversas modalidades, entre elas a tortura, a morte, a privación de liberdade, a depuración profesional, o exilio e as sancións e extorsións económicas. Neste traballo centraremos a atención nas mortes e na depuración profesional do maxisterio galeguista na provincia da Coruña, aínda que tamén faremos algunhas referencias á aplicación da Lei de responsabilidades políticas, o profesorado de ensino secundario e a outras provincias.

\section{Morte}

En Mortos por amor á Terra, Xosé Ramón Ermida Meilán ofrécenos 78 breves biografías de homes que sufriron a represión no seu grao máximo. Algúns militaron no nacionalismo galego e todos sentiron a chamada da Terra. ${ }^{5}$

A nómina de mestres que figuran no libro é relativamente extensa: Antonio Caneda Rodríguez, Ánxel Casal Gosende, Antonio Dopazo Fernández, Rafael Fernández Casas, Isaac Forneiro Barandela, Xosé García Fernández, Francisco García Moldes, Xoán Xesús González Fernández, Amadeo López Bello, Xosé Losada Castelao, Leonardo Martínez Novo, Bernardo Mato Castro, Benigno Rey Pavón, Manuel Rodríguez Castelao e Reinaldo Sarria Delgado, aos que se suman Leandro Carré Brandariz e Modesto Villar Insua, profesores das escolas de traballo. A suma ascende a 17, o que representa aproximadamente un de cada cinco mortos rexistrados por Ermida. Entre eles non existe ningún profesor de

\footnotetext{
${ }^{2}$ Antón Costa Rico, Historia da educación e da cultura en Galicia (Vigo: Xerais, 2004).

${ }^{3}$ Beramendi, De provincia a nación, 909.

${ }^{4}$ Xavier Castro, O Galeguismo na encrucillada republicana (Ourense: Servizo de Publicacións da Deputación Provincial, 1983), I, 173.

${ }^{5}$ Xosé Ramón Ermida Meilán, Mortos por amor á Terra. A represión sobre o nacionalismo galego (1936-1950) (Santiago de Compostela: Sermos Galiza, 2016).
} 
secundaria ou de universidade, e aínda que estes corpos profesionais eran certamente moito máis reducidos, tampouco podemos desbotar que os sublevados, tan respectuosos coas xerarquías sociais, actuasen, tamén neste ámbito, cunha certa perspectiva de clase. ${ }^{6}$ Despois de todo, os mestres eran os "traballadores" do ensino, condición que algúns reclamaban expresamente.

Á marxe destas persoas, houbo outras, igualmente asasinadas, que, sen militaren no nacionalismo, sustentaban ideas e sentimentos galeguistas. No tocante á provincia da Coruña, podemos citar a Ramón Amadeo Figueroa Vilachá (Culleredo), executado no Campo da Rata (A Coruña) en 1937, que foi acusado de "haber hecho propaganda de oradores de un mitin galleguista celebrado en su escuela"; 7 a María Vázquez Suárez (Miño), militante socialista asasinada en 1936 -cada día adquire unha maior dimensión no meu maxín-, que realizou excursións coas súas alumnas a Santiago para visitar a catedral e o monumento a Rosalía de Castro, e a Carral para lles render homenaxe aos Mártires e cantar coas nenas o himno galego; ${ }^{8}$ a Juan Ramón García Niebla, socialista asasinado en Ferrol en 1936, que formara parte das Irmandades da Fala desta cidade ${ }^{9}$; ou a Fernando Barcia Beiras, militante socialista executado en Santiago en 1938, que participou en mitins a prol da aprobación do Estatuto de Autonomía de Galicia e defendeu a necesidade de galeguizar o sistema educativo. ${ }^{10}$ Noutras provincias, e para me referir a persoas sobre as que levo investigado, é indubidábel o compromiso coa Terra do lucense Arximiro Rico Trabada, que militou en Izquierda Republicana -"Arximiro era moi galeguista", confesáronme algúns dos seus antigos alumnos-, como tamén o do pontevedrés Víctor Fraiz Villanueva, que no seu día formara parte do Grupo Autonomista Galego promovido por Valentín Paz Andrade e nos últimos anos da súa vida militou no comunismo, logo de estar adscrito durante varios anos ao socialismo. ${ }^{11}$

Un dos mestres asasinados foi, como xa dixemos, Rafael Fernández Casas. Non é moito o que sabemos sobre os seus primeiros anos, aínda que as investigacións realizadas por Andrés Santalla López e José Manuel Suárez Sandomingo nos fornecen algúns

\footnotetext{
${ }^{6} O$ profesorado do ensino secundario e superior tivo máis peso entre os exiliados, como puxo de manifesto Antón Costa Rico: "Os ensinantes galegos no 36. Os mortos e os exiliados", en A Il República e a Guerra Civil (Actas do Il Congreso da Memoria) (Narón: Asociación Cultural Memoria Historia Democrática, 2006), 487-521.

${ }^{7}$ Expediente de depuración, Arquivo Xeral da Administración (Alcalá de Henares, en adiante, AGA), 32/12510-28. ${ }^{8}$ Juan Sobrino Ceballos e Manuel Domínguez Ferro, "' $i$ Que pouco vale unha mestra!' Un achegamento á figura de María Vázquez Suárez", Cátedra. Revista eumesa de estudios 18 (2011): 209-227.

${ }^{9}$ Guillermo Llorca Freire, "Juan García Niebla. A Pedagoxía ó servicio do cidadán", Idea. Intercambio de experiencias de aula 6 (2006): 106-109.

${ }^{10}$ Luis Lamela García, 1936. La "Cruzada" en Compostela. La Guerra Civil y la represión franquista en los documentos policiales y militares (Sada: Edicións do Castro, 2005), 254-264. Lamela describe así as súas reivindicacións en materia educativa: "Muy en sintonía con las ansias autonomistas del momento, en Ferrol llegó a decir que a los niños gallegos se les enseñaba en las escuelas donde estaba Pekín sin reparar en enseñarle[s] la geografía de su propia tierra, su historia o su literatura. En Santiago puso como ejemplo que a los niños gallegos se les explicaba una lista de batallas de Castilla contra los árabes en la Edad Media, y en cambio no el origen de las luchas de los Irmandiños" (p. 254).

${ }^{11}$ Arximiro Rico, luz dos humildes (Santiago de Compostela: Gesto Dentro Editora, 2002) (en colaboración con Xosé Manuel Sarille) e "Víctor Fraiz Villanueva. Proceso a la FETE y a la escuela republicana", que se publicará proximamente en Historia y Memoria de la Educación.
} 
datos. Naceu en Bos Aires en 1901, e dous anos máis tarde a nai retornou a Galicia cos seus fillos. Ao carecer de recursos para ocuparse deles, ingresounos no hospicio de Santiago de Compostela, onde Rafael permaneceu até os 16 anos. ${ }^{12}$

Cursou estudos na Escola Normal compostelá, que naquela altura tiñan unha duración de catro cursos, logo da reforma realizada en 1914, que unificara a titulación do Maxisterio. ${ }^{13}$ El Compostelano informaba 013 de febreiro de 1922 que o "alumno de cuarto curso" Rafael Fernández Casas impartira na Normal unha conferencia sobre Arquímides, e 012 de setembro do ano seguinte, que se atopaba en Santiago quen agora era "maestro de las escuelas particulares de Palas de Rey". ${ }^{14} \mathrm{~A}$ través deste mesmo diario, cuxo cronista se refería a Rafael como "nuestro amigo", tamén sabemos que en 1920 foi elixido bibliotecario (27/10) e en 1921 secretario (13/4) da Asociación de Mestres e Estudantes Normalistas de Santiago.

En 1923 coñeceu a Victoriano Taibo, a quen xa escoitara aturuxar na praza de touros de Santiago durante a celebración dun festival folclórico, e ese encontro consolidou a súa adhesión ao galeguismo, como el mesmo escribiu:

Correran algúns anos e comenzaba outubre de 1923, cando, sin eu solicitalo, fun presentado por un amigo ao poeta, que desexaba falarme encol da rexencia dunha escola d'emigrados que s'atopaba vacante. Mentras durou a conversa, el falou en galego; eu en castelán, decatándome axiña que o poeta pertenecía á falanxe dos "bos e xenerosos": dos galegos integraes. ${ }^{15}$

A escola da que quería falarlle o poeta era a de Santo Adrao de Veiga (Ortigueira), da que Rafael tomou posesión en xuño de 1924. Seguindo o exemplo de Taibo, procurou incorporar o uso do idioma galego na docencia, por máis que as escolas creadas polos emigrantes non constituísen un escenario particularmente propicio para o noso idioma, por atribuíren os seus promotores unha especial importancia á aprendizaxe do castelán, idioma falado nos principais países de destino da emigración, como Cuba e Arxentina. ${ }^{16}$

Dous anos despois cambiou de destino e fíxose cargo da escola sostida pola sociedade de emigrantes La Devesana, unha das poucas escolas laicas existentes na Galicia da época. O laicismo suscitou as críticas do párroco do lugar, que denunciou a sociedade

\footnotetext{
${ }_{12}$ Andrés Santalla López, "Rafael Fernández Casas", Idea. Intercambio de Experiencias de Aula 7 (2001): 83-85; José Manuel Suárez Sandomingo, "Rafael Fernández Casas, un maestro laico e innovador", Galicia Digital. EI portal de Galicia para el mundo, 11/9/2012. Véxase tamén o libro xa citado de Ermida Meilán, 85-86.

${ }^{13}$ Aurora Marco López e Anxo Serafín Porto Ucha, A Escola Normal de Santiago de Compostela. De Escola Normal Superior a Escola Universitaria (1849-1996) (Santiago: USC, 2000).

${ }^{14}$ El Ideal Gallego publicou 06 de xuño de 1922 a relación de persoas que remataran os estudos de Maxisterio por esas datas, entre as que figuraba Rafael.

${ }^{15}$ Rafael Fernández Casas, "Temos que dar exempro", El Pueblo Gallego, 11/11/1926. Este texto foi reproducido por Heraldo de Galicia (A Habana), 10/4/1927.

${ }^{16}$ Son varios os traballos sobre a actuación dos nosos emigrantes no eido escolar, entre os que citaremos un dos realizados por Vicente Peña Saavedra: Éxodo, organización comunitaria e intervención escolar. La impronta educativa de la emigración transoceánica en Galicia (Santiago de Compostela: Xunta de Galicia, 1991), 2 volumes. Sobre o idioma que se debía utilizar nestas escolas, véxase Antón Costa Rico, "As escolas dos americanos: en castelán ou en galego? 'Moito mal que fan a Galicia', Revista Galega de Educación 53 (2012): $42-46$.
} 
responsábel da escola e ao seu mestre. A denuncia baseábase en que "la mencionada escuela es el medio elegido para alimentar y difundir todo género de ideas disolventes, para ahogar todo sentimiento religioso y sembrar doctrinas perniciosas, habiéndose celebrado en el salón de clases bailes a puerta cerrada, donde las parejas, en su orgía, llegaban a escenas censurabilísimas, que comentadas con fruición fueron tema de escándalo en el país." O gobernador concedeu credibilidade a esta información e acordou clausurar a escola e multar a delegación administrativa de La Devesana con 500 pesetas e o seu mestre con 250, ademais de pór os feitos en coñecemento do xulgado. ${ }^{17}$ Nese momento o mestre aínda non era Rafael, que estaba en Santo Adrao, senón Antonio Pardo Quintas, que será absolto na causa vista na audiencia coruñesa, como tamén Antonio Filgueiras Pita, representante da Devesana; os seus defensores foron Casares Quiroga e Pita Romero. ${ }^{18}$

Ao longo destes anos en Ortigueira, o noso home, ademais de ocuparse dos labores docentes, aos que procuraba imprimir unha orientación innovadora, publicou diversos artigos en diarios e revistas. Nun deles, titulado "Os indianos", loaba o labor realizado polos emigrantes no eido escolar, e sumábase á iniciativa de institucionalizar o Día do Indiano para recoñecer a importante contribución que a parroquia de acolá estaba a facer á Terra. ${ }^{19}$ Tamén publicou unha novela, Loita (1927), e escribiu outra que se perdeu.

Non debeu estar moito tempo en Devesos, xa que en febreiro de 1927 foi nomeado mestre substituto da escola nacional da Gándara (Oroso) ${ }^{20}$ e en 1929 interino da de Naraio (San Sadurniño). ${ }^{21}$ No transcurso dos aproximadamente 18 meses que se rexistran entre 0 cesamento no primeiro destino e a toma de posesión do segundo, sabemos que o recruta Rafael Fernández Casas foi premiado no certame literario convocado no Rexemento de Infantaría Zaragoza. ${ }^{22}$

\footnotetext{
${ }^{17}$ La Voz de Galicia, 28/3/1924. A decisión foi duramente censurada desde A Habana por El Eco de Galicia, que denunciaba a persecución do laicismo por parte do párroco, a credibilidade concedida polo gobernador ás palabras do clero, sen practicar indagacións ao respecto, e a retención e censura por parte do Directorio militar do cable remitido a Cuba polos representantes da Devesana en Galicia. Tamén se facía eco do malestar que en Devesos produciran as "injurias y falsedades" da denuncia, como se poría de manifesto no proceso xudicial que se abriría ao respecto (4/5/1924). Pola súa parte, o Comité Representativo das Sociedades Galegas de Instrución radicadas na Habana dirixiu unha carta de protesta ao ditador, Miguel Primo de Rivera. Nela cualificaba de arbitrario e impropio de países civilizados o proceder da máxima autoridade provincial coruñesa e de "ciega e irreflexiva" a intransixencia do párroco "con aquellos que no quieren que en la Escuela se haga proselitismo religioso de ninguna especie", e solicitaba asemade a reapertura da escola e a investigación dos sucesos para clarificar os feitos e esixir responsabilidades (Heraldo de Galicia, A Habana, 22/6/1924).

${ }^{18}$ Eco de Galicia, 30/8/1925. Non sabemos se houbo outra denuncia cando Rafael rexentaba esta escola, pois segundo Andrés Santalla, Melisendra, a muller do noso protagonista, "sempre lembraba como Rafael tivera que ser defendido polo dúas veces ministro republicano Leandro Pita Romero e polo presidente da República, Casares Quiroga, precisamente por acusacións do cura da parroquia de utilizar a escola laica da Devesana (dos Indianos) para bailes obscenos, de bailes caribeños, con mulleres desnudas, todo isto agochado na escusa de que se rompera un crucifixo durante tal festín" ("Rafael Fernández Casas", 85).

${ }^{19}$ El Pueblo Gallego, 13/11/1926.

${ }^{20}$ El Ideal Gallego, 7/2/1927. Dous meses antes, este mesmo diario informaba que se desestimara a súa pretensión dunha interinidade no ensino público (8/12/1926).

${ }^{21}$ El Eco de Santiago, 29/11/1929.

${ }^{22}$ El Ideal Gallego, 18/12/1928.
} 
Ao pouco de se proclamar a República, resultou elixido secretario do Centro Republicano de Santiago e inscribiuse nos cursos de selección profesional do Maxisterio, que substituían as oposicións tradicionais..$^{23}$ No debate que se produciu entre os participantes acerca da normativa que rexía este novo sistema de acceso á profesión, Rafael defendeu o goberno republicano, e nomeadamente a Marcelino Domingo, dos ataques e insultos de que fora obxecto nunha reunión mantida en Santiago, entre outras razóns por permitir que se presentasen os licenciados, posición que el compartía, "fundándome na savia universitaria que compre inxerir no Maxisterio de Primeiro ensiño". ${ }^{24}$ Para facer valer os seus dereitos, os aspirantes a ingresaren no maxisterio na prometedora conxuntura que se abría en 1931 decidiron organizarse e adscribirse á Confederación Nacional do Traballo. Os elixidos para o comité compostelán de tal confederación foron Pedro López Vázquez, ${ }^{25}$ Luis Canosa, Rafael Fernández Casas, Manuel Gómez, Ramiro Tato, "los señores Isorna, Liste y las señoritas Carmen Nogueira y Sofía López". ${ }^{26}$

Durante o período republicano traballou como mestre interino nas escolas coruñesas da Gaiteira e de San Roque de Afora, ${ }^{27}$ e posteriormente foi destinado á de Souto-Carnoedo, no concello de Sada. Segundo consta no seu expediente de depuración, tomou posesión desta escola o 1 de agosto de 1934, e previamente desempeñara outra interinidade no concello das Pontes. ${ }^{28}$

Nestes anos pronunciou varias conferencias sobre temas educativos. En 1934, nunha das reunións do Centro de Colaboración Pedagóxica coordinado pola inspectora-mestra María Barbeito Cerviño, ${ }^{29}$ disertou sobre a aprendizaxe da literatura e da oratoria no ensino primario, apostando, segundo nos relata o cronista, por algunhas técnicas empregadas nas escolas novas norteamericanas: "Maestros y niños se cuentan historias mutuamente, prefiriéndose, no las leídas en los libros, sino las que se transmiten oralmente." ${ }^{30}$ Ao ano seguinte impartiu outra conferencia sobre o analfabetismo no Ateneo de Cultura Social e Política de Sada, do que foi nomeado presidente en xaneiro de 1936. Unha vez presentado o problema do analfabetismo en España e noutros países, coa axuda de mapas elaborados para tales efectos,

analizó, con gran riqueza de datos demostrativos, la influencia que ejercen en el nivel cultural de los pueblos los regímenes políticos y religiones que estos profesen. Tuvo palabras de gran elogio para la

\footnotetext{
${ }^{23}$ La Voz de Galicia, 6/8 e 3/11 de 1931, respectivamente.

${ }^{24}$ Rafael Fernández Casas, "Á opinión púbrica", El Compostelano, 6/10/1931.

${ }^{25}$ Este cursillista pretendeu polemizar con Rafael nas páxinas d'El Compostelano, pero os responsábeis do diario afirmaban que non podían publicar o seu texto, sen especificar os motivos. Pedro López Vázquez era o nome do mestre de Carnota martirizado no ano de desgraza de 1936.

${ }^{26}$ El Compostelano, 2/11/1931. Dos sete homes citados, seis foron separados definitivamente do ensino ao final do proceso de depuración e [Enrique] Isorna [Couselo] reposto no cargo con dereito a cobrar os haberes deixados de percibir.

${ }^{27}$ La Voz de Galicia informaba dos nomeamentos 0 13/4/1932 e 0 28/9/1933, respectivamente.

${ }^{28}$ AGA, 32/12537-34.

${ }^{29}$ Ana Romero Masiá, María Barbeito. Unha vida ao servizo da escola e dos escolares (1880-1970) (A Coruña: Baía Edicións, 2014), 90-104. Na páxina 98 alúdese á intervención de Fernández Casas.

${ }^{30}$ La Voz de Galicia, 9/6/1934.
} 
obra pedagógica realizada en los primeros tiempos de la República y de condenación para los que ahora, con el fin inconfesado de proteger la enseñanza en colegios privados de tipo confesional, quieren destruirla. ${ }^{31}$

Os fascistas suspenderon de emprego e soldo a Rafael o 19 de agosto de 1936 (BOP do 21); ao día seguinte remataron coa súa vida, abandonando o cadáver nunha cuneta de Trasanquelos (Cesuras); o 26 dese mesmo mes foi destituído, o que supuña prolongar de forma indefinida, e en principio definitiva, a anterior suspensión (BOP do 28); ao ano seguinte publicouse un requirimento para que comunicase o domicilio ao que se lle debía remitir o prego de cargos (BOP, 24/11/1937); en 1938 recoñecéuselle o dereito de retornar á escola mentres non se resolvía o expediente de depuración (BOP, 17/12/1938); un ano despois reiterouse o requirimento de domicilio para os mesmos efectos (BOP, 12/12/1939); e por último, foi separado definitivamente do ensino e dado de baixa na escala (BOP, 21/9/1940).

No expediente que conduciu á súa separación emitíronse os catro informes regulamentarios, tres dos cales -alcalde, garda civil e pai de familia- son idénticos: era un bo docente, mais non promovía nos seus alumnos o amor a España nin o respecto ás institucións básicas da civilización, como a familia ou as clases sociais, e facía labor antirrelixioso na escola; no aspecto social, daba mal exemplo, asistía a centros e reunións que o desprestixiaban, relacionábase con elementos de carácter subversivo e non cumpría cos deberes relixiosos; na súa vida particular, non actuaba coa "dignidad" -a saber o que querían significar os rebeldes con este cualificativo- propia dun mestre, aínda que cumpría as súas obrigas familiares; finalmente, militara no Partido Galeguista e en Socorro Rojo Internacional, participara en mitins e dera conferencias a prol da Fronte Popular, fora presidente do Ateneo de Cultura Social e Política de Sada, estivera afiliado e simpatizaba coa Fronte Popular, pertencera á Asociación de Traballadores do Ensino e ignorábase se fora interventor ou apoderado dos partidos da Fronte Popular nas eleccións. $O$ párroco optou por non contestar ningunha pregunta, e o 19 de xaneiro de 1937 rexistrou o seguinte no apartado destinado a outros datos: "Me considero relevado de contestar a las preguntas anteriores porque la persona a la cual se refieren, anarquista de acción, ha sido ejecutado hace ya unos cinco meses."

"Anarquista de acción" será precisamente o primeiro cargo que lle formule a Comisión depuradora provincial, ao que se engadirán outros tres: pertencer á Asociación de Traballadores do Ensino, contribuír aos gastos electorais da Fronte Popular e facer propaganda a prol desta coalición. ${ }^{32}$ Uns cargos que se lle remitiron a través do alcalde, e que este non puidera entregar "por no residir en este término municipal dicho Maestro y su familia,

\footnotetext{
${ }^{31}$ El Pueblo Gallego, 3/11/1935.

${ }^{32}$ Non 0 acusaron de masón, malia formar parte do mesmo triángulo masónico -Agarimo n. 78- que Enrique Gippini Escoda, José María Pita Cendán e Luis Canosa Gonález. Véxase Alberto Valín Fernández, "Política, apoio mutuo e República: A masonería provincial coruñesa durante a Segunda República", n'A I/ República e a Guerra Civil (Actas do /l Congreso da Memoria) (Narón: Asociación Cultural Memoria Histórica Democrática, 2006), 61-62. Nos expedientes de depuración dos dous primeiros si figura este cargo (AG, 32/12511-4 e 1333530).
} 
ignorando su residencia”. Resulta críbel que Toribio Pollán Nieto, agora alcalde do concello de Sada e delegado de Orde Pública durante primeiros días da sublevación, ${ }^{33}$ descoñecese que Rafael fora asesinado? En todo caso, a Comisión, considerando probada a súa "ideología izquierdista", propuxo a separación do servizo do ensino, como así se fixo. ${ }^{34}$

\section{Depuración}

Foron varios os mestres e mestras coruñeses acusados nos seus expedientes de depuración de pertenceren ou simpatizaren co galeguismo.$^{35}$ Cinguíndonos ás persoas que finalmente foron separadas do ensino, as siglas do Partido Galeguista son, despois do socialismo e de Izquierda Republicana, as que máis se repiten cando se especifica a afiliación partidaria. 0 cargo de militancia galeguista, unida á ideoloxía e propaganda deste mesmo signo, afectaba a case $07 \%$ dos separados definitivamente do ensino, e bastantes máis foron os sinalados como seguidores de Castelao, Suárez Picallo ou Vilar Ponte nos informes redactados por alcaldes, párrocos, gardas civís, pais de familia e outras instancias. $^{36}$

Como é sabido, o Partido Galeguista formou parte da Fronte Popular, polo que algúns dos cargos formulados aos seus afiliados consistían en facer propaganda ou exercer como apoderados ou interventores desta coalición nas eleccións de febreiro de 1936 -a relación coa Fronte Popular será a acusación que teña máis peso nos expedientes por min analizados-. Esta integración facía que os depuradores identificasen o galeguismo co esquerdismo, de aí que nalgúns expedientes se asociasen expresamente ambas as ideoloxías. De José Canle Franco (San Xulián de Vigo-Paderne), que actuara nas eleccións como representante de Suárez Picallo, dicíase que "militaba en el Partido Galleguista y de Izquierda", do que fora "gran propagandista".

Se nos limitamos ás 48 persoas expulsadas do maxisterio para as que se especifica a formación política á que supostamente estaban adscritas, aproximadamente a metade pertencían ao PSOE (25), un cuarto a IR (11), o 10\% ao PG (5), o 6\% ao PC (3), o 4\% a UR (2), o 2\% (1) ao PRRS e outro tanto á FAI. Na investigación realizada por Jesús M. García Díaz sobre o conxunto do maxisterio coruñés -con independencia do resultado da súa depuración- identifícase a afiliación de 216 persoas, das que un terzo estaba adscrita á Falange, que experimentou un crecemento espectacular ao abeiro do fusil dos militares. Se reparamos só en seis das sete opcións políticas antes sinaladas, que suman 101 casos no reconto de García Díaz, a distribución sería a seguinte: PSOE 40\%, IR 22\%, PG 19\%,

\footnotetext{
${ }^{33}$ Carlos Fernández Santander, Alzamiento y Guerra Civil en Galicia (1936-1939) (Sada: Ediciós do Castro, 2007), I, 135.

${ }^{34}$ AGA, 32/12537-34.

${ }^{35}$ Unha primeira visión deste proceso publicouse nas páxinas desta mesma revista: "O proceso de depuración do maxisterio na provincia da Coruña", Sarmiento. Revista Galego-Portuguesa de Historia da Educación 21 (2017): 119-158.

${ }^{36} \mathrm{~A}$ análise dos cargos formulados nos expedientes abórdase nunha investigación que se está a realizar, centrada no profesorado que experimentou algún tipo de sanción como consecuencia da depuración, e nomeadamente naquel que foi afastado definitivamente do ensino.
} 
PC 14\%, UR 5\% e PRRS un único afiliado, que nos serviu para redondear as porcentaxes das cinco opcións restantes. ${ }^{37}$

Manuel Bermúdez Fernández (Sismundi-Otigueira) recoñecía a súa militancia no PG, mais no prego de descargos argumentaba que se afiliara motivado por un sentimento rexionalista, e convencido de que así contribuía ao engrandecemento de España e dos seus valores tradicionais. Neste sentido, lembraba que no galeguismo coexistían dúas tendencias: a dereitista, á que el pertencía, que só aspiraba a unha "autonomía administrativa regional dentro del Estado totalitario", e a esquerdista, que reclamaba asemade a autonomía política. Tamén admitía que presentara a un orador en dous mitins de carácter galeguista celebrados en Mera e Santo Adrao (Ortigueira) -posibelmente se tratase de Antón Vilar Ponte, de quen o mestre fora discípulo desde a nenez, ao dicir do párroco-, mais non exercera como apoderado dos partidos da Fronte Popular, por máis que alguén o propuxese para realizar tal cometido. ${ }^{38}$

Máis intensa e diversificada fora a militancia de Agustín Formoso Piñeiro (Caldebarcos-Carnota): contribuíra á implantación do PG, do que fora secretario; interviñera activamente nas eleccións de febreiro; resultara designado tenente alcalde na xestora municipal configurada a raíz dos resultados de tales eleccións e participara na propaganda a prol do Estatuto de autonomía. Para se defender destas acusacións, o mestre alegou que 0 seu galeguismo fora cultural e non político, argumento ao que se recorreu con bastante frecuencia. ${ }^{39}$ Así o fixo, poñamos por caso, Xosé María Álvarez Blázquez, ${ }^{40}$ e así 0 farán outros aos que nos referiremos nas páxinas que seguen.

Os galeguistas foron os principais valedores do Estatuto de autonomía, e ingresaron na Fronte Popular - malia a resistencia do sector máis dereitista - convencidos de que ese era o camiño que conduciría á súa consecución. De modo que durante a campaña estatutaria se esforzaron en convencer a cidadanía de que a autonomía contribuiría á solución de moitos dos males que padecía a Terra, para o que empregaron todos os recursos de que dispuñan: prensa, manifestos, mitins, radiofonía, carteis ou panfletos.

No expediente de depuración de Jesús Domínguez Pedreira (Cerceda), acusado, entre outros cargos, de "haber firmado el Manifiesto Galleguista", inclúese un exemplar do Estatuto de Galicia que la Asamblea Regional de Ayuntamientos celebrada en Santiago de Compostela durante los días 17, 18 y 19 de diciembre de 1932 acordó proponer a la votación de los electores conforme al artículo 12 de la Constitución -o exemplar foi remitido polo gobernador civil a petición dos depuradores coruñeses-, cuxa aprobación solicitara

\footnotetext{
${ }^{37}$ Jesús M. García Díaz, La depuración del magisterio nacional en la provincia de A Coruña (A Coruña: Fundación Luis Tilve, 2018), 278. Computamos unicamente as adscricións do cadro 3 que se refiren a unha única organización política.

${ }^{38}$ AGA, 32/12519-4.

${ }^{39}$ AGA, 32/12510-29.

${ }^{40}$ Narciso de Gabriel, Xosé María Álvarez Blázquez, mestre republicano. Diario escolar e desterro (Vigo: Galaxia, 2019).
} 
publicamente o mestre, coa agravante, segundo o delegado civil de Cerceda, de asinar como "Xesús". ${ }^{41}$

Francisco Vales Villamarín (A Coruña) foi acusado dun único cargo: "simpatizar" coas doutrinas galeguistas e co proxecto de Estatuto. Todos os informes resultaron favorábeis para o mestre da escola coruñesa dos Castros, malia as súas ideas galeguistas, porque o seu era, como advertía o párroco, "un galleguismo, si así puede decirse, ortodoxo". 0 depurado renega nos descargos do Partido Galeguista e da Fronte Popular, cuxas políticas conducían á "sovietización y desmembración de España", e afirma que as súas actividades extraescolares consistiran na realización de investigacións científicas de carácter histórico ás que alguén atribuíu un significado do que carecían. Afortunadamente para el, na Comisión depuradora coruñesa había dúas persoas, Antonio Eiján Lorenzo, vicepresidente, e Ramón Lamela Cernadas, secretario, que o coñecían e acreditaron "su perfecto españolismo, sentimiento perfectamente compatible con una gran afición que este maestro siente por los estudios referentes a Galicia y de modo singular a la ciudad de Betanzos, aficiones que sin duda fueron las que movieron a los informantes a acusarlo de galleguismo". ${ }^{2}$

Outros mestres acusados de faceren propaganda estatutaria foron César Rodríguez Fernández (negábao afirmando que "era enemigo de toda clase de opresiones y como tal tenía en grado máximo al Estatuto Gallego"), ${ }^{43}$ José Salgado Fernández, Xosé Toba Fernández, Jesús Gustavo Díaz Sánchez, Manuel Alonso Asorey ou Ramón Amadeo Figueroa Vilacha. Asorey interviñera como orador no mitin celebrado en Oza dos Ríos o 20 de xuño de 1936, segundo figuraba nas páxinas de El Pueblo Gallego e certificaba o novo director deste xornal, Jesús Suevos. ${ }^{44}$ Figueroa actuara como presentador noutro mitin que tivera lugar en Culleredo: "Si tal mitin tuviese matiz izquierdista o derechista, sería lo suficiente para que me negase a hacer la referida presentación; pero como era exclusivamente galleguista, accedí por creer que no podía herir los sentimientos de ningún vecino". O argumento carecía de valor para os membros da Comisión depuradora coruñesa, convencidos como estaban de que o mitin "además de galleguista era izquierdista, única propaganda galleguista que se ha hecho en esta zona de la provincia". ${ }^{45}$

Aínda así, os depurados, na procura de atenuantes, insistían en diferenciar ambas as dimensións. Emilio Santasmarinas Mouriño, mestre de Lira (Carnota), recoñecía a asistencia a un mitin a prol do Estatuto e a outro galeguista, celebrados en Muros, mais fixérao por simple curiosidade, atraído pola sona e a verba dalgúns dos oradores. E o seu proceder fora compartido por moitos dereitistas, que non dubidaban en desprazarse varios quilómetros para calibrar a "fuerza dialéctica" despregada por "personajes siniestros de la política española", aos que o inigualábel exército de Franco desterrara definitivamente da "España naciente, prometedora de días de orden estable, de trabajo remunerado, de paz riente y

${ }^{41}$ AGA, 32/12553-51.

${ }^{42}$ AGA, 32/13182-26.

${ }^{43}$ AGA, 32/12532-29.

${ }^{44}$ AGA, 32/12511-11.

${ }^{45}$ AGA, 32/12510-28. 
de alegría consoladora" -tiña ben aprendido o discurso oficial-. Non asistira, no entanto, a un "acto público de sabor galleguista" e "carácter izquierdo-galleguista" que tivera lugar en Carnota, moi preto da súa casa, malia intervir un compañeiro, o mestre Fernando Barcia -será executado, como xa dixemos-, ausencia que ao seu entender era máis significativa que as dúas asistencias anteriores. ${ }^{46}$

Antonio Eiras Sacaluga (San Claudio-Ortigueira), ademais de propagandista do Estatuto, contribuíra ao amaño das eleccións en que o texto resultou aprobado por amplísima maioría, pois el e outros camaradas apropiáranse das actas en branco e rexistraran nelas o voto afirmativo de todos os electores. ${ }^{47}$ José Rodríguez Agrelo (Lesende-Lousame), pola contra, manifestáralle a un compañeiro a súa negativa a participar nesta "farsa": " $Y Y$ se le tenía por galleguista!", advertía o informante. ${ }^{48} \mathrm{Na}$ acta sobre a proposta de sanción a Marcial García Suárez (Santa María-Melide), a Comisión depuradora aludía á "gran fraude electoral" que posibilitara a "escandalosa aprobación del Estatuto Gallego, repelida por la casi totalidad de nuestro españolísimo pueblo". ${ }^{9}$

Son escasas as atribucións desde tipo de ideoloxía e propaganda ás mestras, aínda que algunhas si están rexistradas. De Mercedes Rey González dicíase que "al final de un mitin galleguista celebrado en San Pedro [de Nós (Oleiros)] obsequió a la presidenta con un ramo de flores rojas".$^{50}$ O pai de familia convocado para informar sobre Elvira Losada González (Santiago de Mera-Ortigueira) afirmaba que esta "intentó formar el partido galleguista femenino y en él militaba", e o cura sostiña que o seu marido, Antonio Rivera López, era un dos máis destacados propagandistas do "galleguismo anticristiano". ${ }^{51}$

A principal concentración de mestres galeguistas radicaba no municipio de Rianxo, onde había tres agrupacións do partido -localizadas en Rianxo, Asados e Taragoña-, que en 1936 sumaban 272 afiliados, o que convertía os rianxeiros no terceiro núcleo galeguista de Galicia, só superado por Vigo e Ourense..$^{52}$ Os depuradores coruñeses consideraban que o galeguismo adquirira nesta vila "gran virulencia antiespañola y muy izquierdista". ${ }^{53}$

No informe colectivo asinado pola Garda Civil de Rianxo 027 de agosto de 1936 cualificábanse oito mestras como dereitistas, unha como neutral e outra como indefinida, mentres que os 14 mestres se distribuían en cinco dereitistas -un deles, Vicente Quintáns Castaño, será acusado de galeguista ao se instruír o expediente de depuración-, catro esquerdistas e galeguistas (Xosé Losada Castelao, Manuel Rodríguez Castelao, Florencio Figueira Figueira e Xosé García Trabazo), catro indiferentes e un esquerdista, Martín Gómez Rodríguez, que tamén será cualificado finalmente de galeguista. Debemos concluír

\footnotetext{
${ }^{46}$ AGA, 32/12515-8.

${ }^{47}$ AGA, 32/12525-28.

${ }^{48}$ AGA, 32/12514-42.

${ }^{49}$ AGA, 32/13180-5.

${ }^{50}$ Arquivo Central do Ministerio de Educación (Alcalá de Henares, en adiante ACME), Revisión depuración, caixa $83710-04580334$.

${ }^{51}$ AGA, 32/12519-2.

52 Beramendi, De provincia a nación, 901.

${ }^{53}$ AGA, 32/12512-2.
} 
daquela que aproximadamente a metade dos mestres rianxeiros participaban da ideoloxía galeguista, circunstancia que dificilmente se repetiría nalgún outro concello, e ademais eran eles os que representaban a esquerda a nivel local. ${ }^{54}$

Así quedou rexistrado no expediente de Xose García Trabazo, acusado polo alcalde de formar parte do "galleguismo izquierdista nacionalista", que se enfrontou ao seguinte cargo: "Militar en el partido galleguista de izquierdas, banderín político del Frente Popular en el municipio de Rianjo". A súa resposta foi a seguinte:

No quiero negar que, aunque no pertenecía a ningún partido político, he sido simpatizante del galleguista de izquierdas, debido, quizá, a que, falto de experiencia política, han influido en mí las amistades, hasta el extremo de verme arrastrado a ser apoderado de izquierdas en las elecciones de febrero del 36 , sin darme cuenta de la enorme responsabilidad en que incurría, lo que confieso con toda sinceridad. Pero también espero se me tendrá en cuenta el no haber pertenecido al "Socorro Rojo Internacional", ni estar afiliado a "Trabajadores de la Enseñanza" ${ }^{55}$

Vicente Quintáns Castaño deberá responder de se afiliar ao galeguismo, Florencio Figueira de permitir que se afiliase o seu fillo e de asistir el mesmo a reunións de carácter galeguista, e Martín Gómez Rodríguez de participar dos ideais galeguistas e relacionarse co propio Florencio e cos irmáns Castelao -Xosé Losada Castelao e Manuel Rodríguez Castelao-, que semellaban ser os principais líderes nesta bisbarra.

Os irmáns Castelao morreron no interior do bou Eva, ancorado no porto de Vigo, na madrugada do 23 de abril de 1937, e serán separados do ensino polo Ministerio transcorridos máis de tres (Manuel) ou catro (Xosé) anos. ${ }^{56}$ Tamén foron separados Xosé García Trabazo e Florencio Figueira Figueira, mentres que Martín Gómez Rodríguez foi suspendido de emprego e soldo durante tres meses, trasladado e inhabilitado para exercer cargos directivos e de confianza.

Pola súa banda, Vicente Quintáns Castaño, malia alegar que abandonara o PG cando este optara por aliarse coas esquerdas, como tamén fixeran Vicente Risco e Filgueira Valverde, foi trasladado fóra de Galicia, que era a sanción reservada aos nacionalistas. A mesma sanción recaerá en Arturo Arceo Fraiz, Emilia Cubeiro Castro, Horacio Fernández Gómez, Germán Fernández Lemos, Marcial García Suárez e Josefa Losada Vázquez; en fase de revisión, recibirán idéntico castigo outros, como José Canle Franco e Manuel Bermúdez Fernandez. 0 desterro adoitaba concretarse nunha escola de Castela: "Con el traslado fuera de las provincias Gallegas a una aldea castellana entiendo era suficiente",

\footnotetext{
${ }^{54}$ AGA, 32/13180-9.

${ }^{55}$ AGA, 32/12512-2.

${ }^{56}$ Sobre os irmáns Castelao, véxase Xosé Comoxo e Xesús Santos, Rianxo na súa historia. Consecuencias da Guerra Civil (1936-1939) (A Coruña: Deputación Provincial da Coruña, 2010), particularmente as páxinas 225242. Tratei con algo máis de extensión a represión que sufriron estes dous mestres en "Os mestres mortos daquel verán", A Trabe de Ouro 108 (2018): 15-34.
} 
escribía unha man non identificada no expediente de Arturo Arceo Fraiz, para quen se pedía a separación. ${ }^{57}$

Entre o profesorado depurado e sancionado no ensino secundario tamén había militantes galeguistas. Segundo un rexistro ministerial localizado no Arquivo Xeral da Administración polo profesor Olegario Negrín Fajardo, nos institutos de Galicia foron depurados 99 profesores, dos que resultaron sancionados 25 -unha porcentaxe similar á rexistrada no conxunto do Estado-. Entre os sancionados, 18 fórono coa separación definitiva do ensino, e algúns deles profesaban o galeguismo: Carlos Maside, Álvaro de las Casas, Bibiano Fernández Osorio ou Ramón Otero Pedrayo. Xosé Filgueira Valverde, que promovera a constitución da Dereita Galeguista, foi confirmado no seu cargo no Instituto de Lugo ${ }^{58}$ Este rexistro, aínda que non é exhaustivo, constitúe un bo punto de partida para quen desexe profundar nesta cuestión.

Como podemos ler na proposta de resolución do seu expediente de depuración en fase de revisión -o expediente inicial non o conseguimos localizar-, don Ramón Otero Pedrayo fora separado definitivamente do ensino mediante orde do 21 de agosto de 1937 por ser un destacado dirixente do Partido Galeguista -faise notar que tal partido estaba integrado na Fronte Popular, e convivía, xa que logo, co comunismo-, ao que representara en numerosos actos públicos, entre eles un a prol da autonomía organizado en Barcelona, e atendendo asemade á súa condición de ex-deputado. Na proposta tamén se fai constar que fora sancionado polo Tribunal de Responsabilidades Políticas da Coruña en 1941, 0 que corroboraba a fundamentación do castigo anterior. Carecía, porén, de antecedentes masónicos, ao dicir do Tribunal Especial para a Represión da Masonaría e o Comunismo, e o Xulgado Superior de Revisións consideraba que

\begin{abstract}
aparece comprobado en el expediente la ideología católica del Profesor que nos ocupa, defendida por él en todo momento, incluso en los medios hostiles, como las Cortes Constituyentes de la República a las que perteneció, [lo] que ya en 1937 motivó el que D. Eugenio Vegas, Vocal de la Comisión de Cultura y Enseñanza de la Junta Técnica del Estado, formulase voto particular en el sentido de imponer a este Catedrático solamente la sanción de traslado fuera de la región gallega, lo que unido a la actitud del interesado de colaboración con el Régimen español, permite aplicar el criterio de benevolencia que inspira los actos del Gobierno para que pueda ser readmitido al servicio de la enseñanza, pero alejado de la región gallega donde tanto por sus antiguas ideas galleguistas, difíciles de desarraigar en una persona que ha cumplido sesenta años, cuanto por haber sido pública la actuación destacada en la política de aquel carácter, sería peligrosa e impopular la intervención de este Profesor en la enseñanza pública.
\end{abstract}

\footnotetext{
${ }^{57}$ Sobre a depuración do maxisterio galeguista nas provincias de Ourense e Pontevedra poden consultarse os traballos de Xosé Manuel Cid Fernández, Educación e Ideoloxía en Ourense na Ila República (Santiago de Compostela: Andavira Editora, 2010) e Anxo Serafín Porto Ucha, Mestras e mestres pontevedreses depurados polo franquismo. Primeiras accións represivas e estudo por concellos no sur da provincia (1936-1942) (Ponteareas: Edicións Alén Miño, 2008).

${ }^{58}$ Olegario Negrín Fajardo, "La depuración franquista del profesorado en los institutos de segunda enseñanza de España (1937-1943). Estudio cuantitativo para Galicia”, Sarmiento. Anuario Galego de Historia da Educación 10 (2006): 59-99.
} 
En atención a estas consideracións, o xuíz propuxo, con data do 12 de xuño de 1948, que se lle permitise reincorporarse á profesión coa sanción de traslado fóra de Galicia, imposibilidade de solicitar vacantes durante tres anos e inhabilitación para o exercicio de cargos directivos e de confianza. ${ }^{59} \mathrm{O}$ Ministerio de Educación prescindiu das sancións propostas polo Xulgado e permitiulle reintegrarse ao Instituto de Ourense, onde permaneceu até que en 1950 gañou a cátedra de Xeografía na Universidade de Santiago. ${ }^{60}$

En 1982 don Ramón foi rehabilitado, para todos os efectos, como Catedrático de Instituto de Xeografía e Historia, e considerado, a título póstumo, membro de honor do Claustro do Instituto de Ourense; a orde, asinada por Mayor Zaragoza, tamén declaraba "nulo, con efectos retroactivos, y sin valor jurídico alguno, el expediente de depuración", e nomeadamente o prego de cargos, a proposta de sanción da Comisión de Cultura e Ensino á Xunta Técnica do Estado e a resolución final por esta adoptada (BOE, 1/12/1982). Seguro que don Ramón gozaría lendo a resolución. ${ }^{61}$

Outro profesor de ensino secundario depurado -malia non figurar no rexistro que serve de base á investigación do profesor Negrín- foi Xesús Ferro Couselo, que estaba destinado no Instituto de Tui. ${ }^{62}$

A Comisión depuradora $\mathrm{C}$ de Pontevedra formulou un único cargo na súa contra, baseado nos informes recibidos da alcaldía e forzas de orde pública de Tui: "Haber sido elegido el día 10 de Mayo de 1936 Presidente de la Juventud galleguista, de cuyo ideal separatista era un ferviente propagandista."63 0 cargo foille remitido a través da Delegación de Orde Pública de Vigo, que non puido entregar o sobre ao seu destinatario por non residir nesta cidade, aínda que o delegado soubera, a través do alcalde de Tui, que se desprazara a Madrid para realizar uns cursos e que non regresara. En consecuencia, e como era preceptivo, foi requirido para que comunicase o seu domicilio a través do boletín oficial provincial do 4 de marzo de 1937. En todo caso, os depuradores xa estaban ao tanto do seu paradoiro, pois o secretario do Instituto de Tui, Teodoro Aparicio, fixéralles chegar copia dunha carta que enviara a finais de xaneiro ao pai de "mi inolvidable amigo y compañero Jesús", de quen por fin tiñan novas no centro: "La noticia ha sido indirecta, por medio de una tarjeta especial de la Cruz Roja, fechada el 21 de Diciembre último, que dirigía una compañera también de este Instituto que se encuentra en Madrid al hoy Director del Centro compañero Iribarren. En tal tarjeta, de su puño y letra, agregaba Jesús Ferro: 'saludos a todos"'.

\footnotetext{
${ }^{59}$ ACME, Revisión depuración, caixa 83715-4183.

${ }^{60} \mathrm{O}$ que non logrou don Ramón foi que se lle aboasen os haberes deixados de percibir durante o longo período de separación da profesión (BOE, 5/10/1949).

${ }^{61}$ Existen varias biografías sobre quen foi, durante moitos anos, o Patriarca das Letras Galegas, entre elas unha de Carlos Casares, compilada en Conciencia de Galicia. Risco, Otero e Curros. Tres biografías (Vigo: Galaxia, 2004).

62 Sobre a depuración neste instituto, véxase Lucio Martínez Pereda, "La depuración franquista del Instituto de Vigo: una primera aproximación", Boletín do Instituto de Estudios Vigueses 14 (2008/2009): 183-208.

${ }^{63}$ Expediente de depuración de Xesús Ferro Couselo, AGA, 32/16751-27. Sempre que non se sinale outra procedencia, a documentación citada corresponde a este expediente.
} 
Coñecedor de tal requirimento, o seu tío e conselleiro, Xosé Couselo Bouzas, catedrático do Seminario de Santiago de Compostela, deuse présa en asumir a defensa do sobriño, que "está prisionero de los rojos en Madrid y no puede contestar." Fíxoo con absoluta suficiencia e contundencia, e limitouse a formular unha afirmación que presenta como preámbulo e realmente constituía a conclusión da súa argumentación: pór en cuestión o seu sobriño era tan temerario como dubidar do arcebispo de Compostela, nada menos. "Mi sobrino, tan ortodoxo como el Arzobispo de Santiago, que trabajó siempre por las derechas, incluso en las últimas elecciones contra el Frente Popular en el ayuntamiento de Valga, en donde fue presidente de uno de los colegios, no puede ser tachado en ninguna cosa. Sirva de preámbulo."

Uns días antes, o director do instituto, Luis María Iribarren, alegando que o expedientado non estaba en condicións de responder aos cargos, tamén considerou oportuno informar á Comisión depuradora nos seguintes termos: durante os dous anos de permanencia en Tui, o comportamento de Ferro Couselo fora "ejemplar"; como vicedirector, que con frecuencia se viu obrigado a asumir funcións de director, "defendió con tesón y energía el prestigio del Centro contra las intromisiones del frente popular"; era galeguista, certamente, mais "distaba mucho de ser separatista y laico", pois o seu era "un sentimiento de acendrado amor a la Región Gallega dentro de la unidad Nacional y del Catolicismo más ortodoxo"; a súa pertenza á organización xuvenil Ultreya -a cuxa organización en Tui contribuíra-, como tamén ao Seminario de Estudos Galegos, debía enmarcarse no seu afán de investigar castros e mosteiros; e as súas ideas eran sas, como demostraba a revista escolar TUDE, por el fundada, e da que remitía un exemplar, no que colaboraba outro entusiasta dos castros, Xosé María Álvarez Blázquez, cun traballo titulado precisamente "Castro de 'A Guía"'.64

0 relator encargado de examinar en primeira instancia o expediente considerou probado o seu galeguismo "separatista", pero tamén que a súa conduta relixiosa, moral e profesional fora "intachable", polo que se limitou a propor o traslado a outro centro, medida que foi asumida pola Comisión depuradora pontevedresa o 26 de abril de 1937. $\mathrm{Na}$ proposta final, asinada polo gobernador civil, matizábase o separatismo ao que aludía 0 relator, que casaba mal cunha sanción tan relativamente benévola: "aparece simpatizando con el titulado partido galleguista sin que haya tenido participación directa ni indirecta en la subversión separatista." A Comisión de Cultura e Ensino acordou, con data do 28 de xullo de 1937, suspendelo de emprego e soldo mentres non estivese en condicións de presentar os descargos e se resolvese definitivamente 0 expediente.

De momento estaba en Madrid -onde se trasladara co propósito de participar nunhas probas de acceso ao profesorado de ensino secundario-, ${ }^{65}$ aínda que non preso dos roxos, como afirmaba o seu tío, senón afiliado á Confederación Nacional do Traballo.

\footnotetext{
${ }^{64}$ Do expediente de depuración deste mestre ocupeime en Xosé María Álvarez Blázquez, mestre republicano.

${ }^{65}$ No prego de descargos redactado en 1939 facía constar que xa se presentara ás oposicións de Filosofía en 1933, e que resultara eliminado no último exercicio "por ser elemento clerical, enemigo de los principios defendidos por la república". Ao dicir de Francisco Fariña Busto, responsabilizaba á FETE da discriminación de
} 
Non sabemos o que pasou pola súa cabeza nos primeiros días da sublevación militar. É posíbel que non deixase de preguntase quen eran realmente os seus -como dicía o outro, "esperemos que non gañen os nosos"-. Por unha banda, como militante galeguista, formaba parte da Fronte Popular, que permitira a aprobación do Estatuto de Autonomía entregado por esas mesmas datas ás autoridades centrais. Por outra, era un católico convencido e practicante, o que o distanciaba do frontepopulismo de carácter revolucionario, abertamente anticlerical, tanto na súa ideoloxía como na súa actuación. ${ }^{66}$

Tampouco sabemos se pensou na posibilidade de abandonar Madrid, caso de resultar factíbel. En Galicia tiña a familia e os amigos, mais non había ningunha garantía de eludir a represión, nin sequera o acubillo da sotana do tío Xosé. Tamén era católico practicante o seu amigo Darío Álvarez Limeses, médico de Tui, e porén, fora fusilado, provocando o estrondo dos fusís un berro que se mantivo vivo de por vida na gorxa do seu fillo Xosé María Álvarez Blázquez. En Madrid, á súa vez, a militancia galeguista tampouco constituía unha garantía de supervivencia. ${ }^{67}$

Había que buscar outro abeiro, e o noso protagonista atopouno nas antípodas da sotana do tío: a Confederación Nacional do Traballo. Así o recoñece na declaración xurada que se viu obrigado a asinar en Madrid o 13 de abril de 1939, na que por certo non alude á súa integración nas Milicias Populares Galegas en agosto de 1936 coa tarxeta número 40 e a afiliación de galeguista. ${ }^{68}$ Á pregunta referida á militancia en partidos políticos e aos cargos desempeñados contesta así:

En diciembre de 1931 ingresó en el Partido Galleguista, grupo de Vigo, habiendo colaborado dentro del grupo que editaba el Boletín católico mensual "Logos" de Pontevedra. En las elecciones actuó siempre en el Ayuntamiento de Valga, juntamente con los elementos de derechas, como podrán testificar las

que foran obxecto el e outros católicos nestas probas. Véxase Ferro Couselo (Vigo: Ir Indo, 1996), 14. Nas probas realizadas en Madrid a comezos do verán de 1936 tamén participaron outros galegos, como Ricardo Carvalho Calero, que as describía así en conversa con Carmen Blanco: "Había, primeiro, uns cursos para profesores encargados de curso, aspirábase a sustituír o sistema de oposicións para entrar no funcionariado docente por outro sistema que se pretendía máis racional, de maneira que había unha serie de exercicios eliminatorios, pero non eran propiamente oposicións, porque non había un número determinado de prazas, senón que aqueles que se consideraban aptos serían enviados onde fixeran falla e logo se aspiraba a que se fixesen as correspondentes prácticas e ao cabo de certo tempo, mediante outros exercicios ou mediante calquera outro sistema de selección, quedaran incorporados ao profesorado como numerarios." Por certo, Carvalho conta que mantivo correspondencia con Ferro cando este "era secretario dun ministro anarquista" (Conversas con Carballo Calero, Vigo: Galaxia, 1989, $29-30$ e 86). Sobre "as probas interrompidas" e "as oposición nonnatas" do verán de 1936, véxase Claudio Rodríguez Fer, A literatura galega durante a Guerra Civil (1936-1939) (Vigo: Xerais, 1994), 253-259; o autor fai notar a presenza desta experiencia na novela Scórpio (Sotelo Blanco: Santiago de Compostela, 1987).

${ }^{66}$ Sirva como exemplo da militancia no catolicismo a súa contribución á organización do ensino do catecismo en Cordeiro (Valga), o lugar onde nacera, cando a República implantou o laicismo escolar. Véxase Felipe Senén e Carlos Díaz Martínez, Xesús Ferro Couselo. A búsqueda da identidade e o encontro cos devanceiros (A Coruña: Espiral Maior, 1996), 24. "A fe cristiá foi un dos grandes principios que rexeron a vida e obra de don Xesús", conclúen Xesús Portas Ferro e Gumersido A. Campaña no traballo titulado "Xesús Ferro Couselo: Un home do pobo para o pobo", Encrucillada. Revista Galega de Pensamento Cristián 97 (1996): 131.

${ }^{67}$ Sobre o Madrid destes anos, pode lerse a descrición que fai Jorge M. Reverte en La Batalla de Madrid (Barcelona: Crítica, 2004).

${ }^{68}$ Marcos Valcárcel, Xesús Ferro Couselo. Unha fotobiografía (1906-1975) (Vigo: Xerais, 1996), 24. 
autoridades políticas y gubernativas del referido municipio. En 1933, como afiliado a la Casa Social Católica de Vigo, fue elegido Secretario del Sindicato Católico de Oficios Varios. No desempeñó en dicho partido ni en el mencionado Sindicato ningún otro cargo.

En 23 de diciembre de 1936 ingresó en el Sindicato Único de la Enseñanza de Madrid, con el fin de luchar contra la tiranía marxista de la F.E.T.E. Por designación de sus compañeros de la Sección de Enseñanza Media y Superior -de derechas, puede decirse, en su totalidad- fue elegido miembro del Comité Central del referido Sindicato, cargo que, como podrá probar con innumerables testimonios, utilizó para la defensa de sus compañeros y de otras personas perseguidas -dando avales, utilizando influencias, procurando colocaciones y facilitando informes-y para luchar contra el predominio marxista en el ramo de la Instrucción Pública.

O Sindicato Único do Ensino, adscrito á CNT, contaba cuns 22.000 afiliados e competía coa FETE, que sumaba arredor de 30.000, polo control da instrución pública. Durante o mandato do ministro Jesús Hernández, o protagonismo correspondeu aos fetistas, e máis concretamente aos comunistas e seguidores de Largo Caballero, pero en abril de 1938, cando Negrín nomeu ministro do ramo a Segundo Blanco, serán os cenetistas os que asuman os principais cargos e responsabilidades. Unha das acusacións que a FETE facía á CNT era, precisamente, a de estar infiltrada pola reacción. ${ }^{69}$

Pois ben, como consecuencia desta mudanza no ministerio, Ferro Couselo foi nomeado secretario do delegado de Instrución Pública en Madrid, Francisco Rojas Bermúdez, que o designou secretario do Instituto para Obreiros da capital "con el exclusivo objeto de luchar contra el tinglado comunista establecido en aquel Centro y de figurar en nómina", segundo el mesmo afirma na devandita declaración xurada. ${ }^{70} \mathrm{~A}$ nómina ascendía a 5.000 pesetas anuais, que lle correspondían como cursillista que aprobara os exercicios de acceso ao profesorado de Filosofía realizados no verán de 1936, ás que se sumaban 250 pesetas mensuais en concepto de gratificación polo seu traballo na delegación do ramo.

Son numerosas, e nalgún caso moi relevantes, as persoas que loan a súa conduta durante estes anos. Daniel de la Sota Valdecilla, na súa condición de comandante de Enxeñeiros e xefe militar das Milicias Clandestinas de Enxeñeiros de Madrid, onde permanecera durante toda a guerra, escribía en 1940 acerca do noso home:

\begin{abstract}
El desbordamiento inmediato de las masas rojas, traducido en persecuciones, crueldades y asesinatos sin número, le hizo ver claramente la necesidad de reaccionar, ocupando posiciones desde las cuales defender vidas e intereses Nacionales. El recurso de que mejor podía usar era su condición de catedrático, que aprovechó para proveerse de un carnet de galleguista que le extendieron como si realmente lo hubiera sido con fecha anterior al 18 de Julio de 1936: esto le permitió conocer por dentro primero y actuar después intensamente en la Federación de Trabajadores de la Enseñanza. Dentro de esta organización, con su prudencia, con su discreción, con su energía sin desmayo, con su entrega a prueba de riesgos, luchó siempre ventajosamente contra elementos comunistas de gran empuje, logrando ocupar puestos que le sirvieron para salvar altos valores artísticos y literarios; para prevenir persecuciones
\end{abstract}

\footnotetext{
${ }^{69}$ Francisco de Luis Martín, La FETE en la Guerra Civil española (1936-1939) (Barcelona: Ariel, 2002), 43-73.

${ }^{70}$ Esta é a descrición que fai na declaración xurada da cúpula do Ministerio de Instrución Pública controlado pola CNT: "Ministro, un metalúrgico, asesino en Asturias; Subsecretario, un 'santón' de la F.A.I. de barba nazarena y acciones de rufián; Directora General de Primera Enseñanza, Esther Antich, la más inteligente de todos, pero entregada en cuerpo y alma a la F.E.T.E. y afanosa de hacerse su 'avío'."
} 
a significados militantes de nuestra organización clandestina; para con avales de otros o con el suyo personal conseguir la libertad de presos en checas del S.I.M.; para nombrar profesores en escuelas 0 institutos rojos a falangistas que, a su vez, prestaban en esos destinos señalados servicios a la Causa Nacional, bien captando noticias convenientes a nuestra información, bien aportando sus haberes a la organización de Socorro Azul.

O texto ten varias imprecisións, como afirmar que Ferro Couselo improvisou a militancia galeguista en 1936 ou a adscrición á FETE, pero polo demais seguramente recolle bastante ben a súa actuación, da que se citan varios exemplos. Unha actuación corroborada por Ramón Fernández Pousa, delegado do Servizo Español do Profesorado en agosto de 1939 e camisa vella das JONS galegas de 1933, credenciais ás que suma outras cinco e dous etcéteras para subliñar o valor da súa sinatura. A militancia na CNT do agora expedientado obedecía unicamente ao seu propósito de combater o comunismo, sabotar os roxos e protexer os falanxistas, o que supuxo que mesmo fose detido durante o período da Xunta do coronel Casado:

Cuantos servicios han sido solicitados de él para Falange, han sido despachados con seguridad absoluta a pesar de ser estos innumerables. Colocación de Catedráticos y Profesores de Falange en las Milicias de la Cultura, colocación de profesores en centros de Enseñanza para resolver así su insostenible situación económica y el certificado de trabajo, certificados de trabajo en el Instituto Ferrer, uno de los mejores sabotajes a la Causa Marxista, disfrazando a frailes y religiosos de todas categorías etc. etc.

Pola súa banda, Santiago Montero Díaz, que coincidira con el en Madrid antes de conseguir pasar á zona "nacional", sostén que tanto a incorporación ao comité central do Sindicato do Ensino da CNT, onde permaneceu desde mediados de 1937 até marzo de 1938, como a aceptación do cargo de secretario da Delegación de Instrución Pública de Madrid foran sometidas á consideración previa de persoas afectas ao Movemento, e ambos cargos foran utilizados para prestar axuda a persoas perseguidas ou indocumentadas, nalgún caso a petición do propio Montero Díaz. ${ }^{71}$

Son, pois, dúas as militancias de carácter político que Ferro Couselo recoñece na declaración xurada de abril de 1939, Partido Galeguista e Confederación Nacional do Traballo, mais o significado que para el tiveron semella ser ben distinto. Ao PG afiliouse por compartir un ideario e un sentimento, e o seu compromiso mantívose na posguerra, como pon de manifesto a participación na tentativa de reactivar o Partido Galeguista e noutras iniciativas culturais do mesmo carácter. ${ }^{72}$ Ao segundo seguramente se afiliou na procura dun refuxio, dado que no Madrid de 1936, onde a vida valía ben pouco, o carné da FETE ou da CNT constituían un salvoconduto moito máis poderoso que o livián carné do PG, e

\footnotetext{
${ }^{71} \mathrm{Na}$ mesma liña informan Adrián Cabezas Osegueda e María Núñez de Cabezas; Manuel García Paredes, arquiveiro, que colaborara con el no Sindicato de Ensino e o propuxera para a redacción do periódico Orientaciones e outros cargos; e Matilde López Serrano, igualmente arquiveira, que subliñaba a súa participación na "salvaguarda y defensa del Patrimonio Artístico Nacional, apoyando desde su puesto en el Ministerio los puntos de vista del grupo nacionalista que trabajaba en el Tesoro Artístico de Madrid, en el que figuraba quien suscribe".

${ }^{72}$ Francisco Fernández del Riego, O río do tempo. Unha historia vivida (Sada: Ediciós do Castro, 1990).
} 
unha vez descartada a primeira, á que Ferro ollaba con moita prevención, como xa anticipamos, só restaba a segunda.

Xesús Portas Ferro e Gumersido A. Campaña, que o coñeceron, apostan, no entanto, por outra explicación. Na súa opinión, "comungou sinceramente coas ideas libertarias, aínda que mantivese as súas reservas verbo dalgunhas partes deste ideario."73 Podería ser que nel aniñase efectivamente unha certa pulsión libertaria, pero o seu perfil -advirto que nin o coñecín nin teño un coñecemento en profundidade da súa traxectoria vital, se exceptuamos o expediente de depuración- coido que discrepa en varios aspectos do que adoitamos atribuír a un activista da CNT, e non digamos da Federación Anarquista Ibérica, á que ás veces foi adscrito. ${ }^{74}$ Sexa como for, unha vez sindicado, aproveitou a súa posición para axudar a quen o necesitaba, como sostén Francisco Fariña Busto: "Axuda, pois, a todos cantos pode, dende os seus compañeiros galeguistas ata os chamados quintacolumnistas."75 Tal actuación solidaria seguramente está relacionada coas súas profundas crenzas relixiosas, como conclúen Portas e Campaña: "A fe cristiá inspirou e sostivo, coidamos, esta actitude."176 0 propio Ferro, en tarxeta dirixida aos pais 028 de marzo de 1939, describía así estes seus anos en Madrid:

\begin{abstract}
Mi pasado ha sido enteramente digno. Hoy lo he enterrado. [...] En los puestos donde por las circunstancias y con una mira suprema logré situarme no procuré otra cosa que aliviar el dolor de los demás. He vivido mucho y sufrido también mucho, no por mí, aunque me vi expuesto a serios peligros, sino por tantos a quienes he procurado ayudar en su desgracia. ${ }^{77}$
\end{abstract}

Toda a documentación sobre o período madrileño formará parte do expediente de depuración, que se reactivou en 1939. 027 de abril deste ano, o Ministerio de Educación Nacional devolveuno á Comisión depuradora pontevedresa para que localizase 0 expedientado, lle fixese chegar os cargos e ratificase ou modificase a proposta anterior.

Os descargos foron asinados en Valga o 12 de xullo dese mesmo ano. Antes de entrar en materia, Ferro Couselo deixa constancia da súa traxectoria formativa no Seminario (doutoramento en Teoloxía) e na Universidade de Santiago (licenciatura en Filosofía e Letras), así como da súa andaina profesional, iniciada en setembro de 1931 no Colexio

\footnotetext{
${ }^{73}$ Portas Ferro e Campaña, "Xesús Ferro Couselo", 134.

${ }^{74}$ Carlos Casares describía así o faladoiro de Vicente Risco en Ourense: "Estaban tamén os galeguistas, un dos cales, Xesús Ferro Couselo, membro da Real Academia Galega, pertencera á FAI en Madrid, e mantiña unha actitude política clara, con actividades na clandestinidade. Este home, pequeno e rexo, de carácter forte, católico practicante e fervoroso, cando se falaba de política, expresábase con prudencia, pero tamén con valentía" (citado en ibidem., 122-123).

${ }^{75}$ Fariña Busto, Ferro Couselo, 15

${ }^{76}$ Portas Ferro e Campaña, "Xesús Ferro Couselo",135.

${ }^{77}$ Citado por Fariña Busto, Ferro Couselo, 15-16. Unha das persoas ás que se cadra prestou axuda escribiulle 0 seguinte desde Vinaroz 07 de novembro de 1937: "Sinceramente te aseguro que te estimo como amigo a quien quiero con todo mi corazón. Que tengo tanto que agradecerte que no sabría hacerlo suficientemente nunca. Pero al mismo tiempo me pregunto si no harías conmigo como con otra persona cualquiera, por esa virtud tan característica tuya, la humanidad, caridad o galleguismo? Claro que esto me obliga a estimarte mucho más y a darte gracias en mi nombre y en el de la humanidad" (citado por Portas Ferro e Campaña, "Xesús Ferro Couselo", 137).
} 
Apostol Santiago que os xesuítas tiñan en Vigo. Unha vez disolta a Compañía, el e outros xesuítas, "que vestían de seglares, establecimos un colegio que se llamó 'Labor' con los alumnos del extinguido Colegio del 'Apostol Santiago'", e nel permaneceu até finais de novembro, data en que se incorporou ao instituto de Tui como profesor de Latín e de Filosofía. Polo demais, subliña o catolicismo que impregnou a súa vida, como evidenciaba a colaboración na revista católica Logos, a pertenza a Acción Católica de Vigo ou a asunción da secretaría do Sindicato Católico de Oficios Varios desta mesma cidade. Tamén fai saber que actuara a prol das dereitas en todos os procesos electorais que tiveron lugar no concello de Valga. ${ }^{78}$

No tocante ao cargo concreto que se lle formulaba, nega que fose separatista, e explica así a súa suposta designación como presidente da "Juventud Galleguista":

Un grupo de jóvenes que habían pertenecido a los "Ultreyas" trató a mediados de Mayo [de 1936] de reorganizarse, en vista del predicamento que iba tomando la Juventud Socialista Unificada. Se me invitó para ello, y en una reunión se tomó el acuerdo de denominar, en vista de que las circunstancias habían variado, Juventud Galleguista al grupo que se formaba. No por eso tendría ni tuvo concomitancias con el Partido Galleguista. Este se encontraba entonces dividido, y las Juventudes que se denominaban galleguistas, en su mayoría de tendencia católica, se habían declarado contra el Partido por su alianza con el Frente Popular y al lado de la derecha galleguista.

Mi actuación en dicha Juventud, se limitó a asistir a su constitución, que ni siquiera fue "legal", pues no tuvo Estatutos ni se dio conocimiento al Gobierno Civil como era obligado, y a ir, creo que tan solo, a otra reunión, en la que para nada se trató de asuntos políticos sino culturales. ${ }^{79}$

A Comisión depuradora acordou finalmente, en abril de 1940, rectificar a proposta inicial -traslado fóra de Galicia-, e propor que se lle recoñecese o dereito a ser reposto na cátedra ou noutra que puidese conseguir, atendendo, entre outras consideracións, á súa moi estimábel contribución ao Alzamento na cidade de Madrid. O Ministerio de Educación ratificou a proposta e decidiu confirmalo no cargo (BOE, 9/7/1940).

\section{Responsabilidades políticas}

Ademais de sufriren a depuración profesional, algúns profesores foron sometidos á Lei de responsabilidades políticas aprobada o 19 de febreiro de 1939. Unha lei que castigaba calquera tipo de disidencia, e mesmo a indiferenza, e que recollía, entre outras penalidades, as sancións económicas, aínda que a súa finalidade non era, agás nos primeiros momentos, principalmente recadatoria, senón política: "contribuir a paralizar cualquier resistencia de los desafectos y forzar a la colaboración activa de los disidentes, prolongando

\footnotetext{
${ }^{78} 07$ de xuño de 1939, tres destacados representantes das dereitas de Valga asinan un documento manifestando que o designaran interventor nas eleccións de febreiro de 1936. A Garda Civil de Tui, pola súa banda, afirmaba que fixera propaganda a prol da Fronte Popular. É posíbel, por tanto, que apoiase candidaturas de diferente natureza nun e noutro escenario.

79 Sobre os Ultreya, véxase Uxío-Breogán Diéguez Cequiel, Álvaro de las Casas. Biografía e documentos (Vigo: Galaxia, 2003). Ferro Couselo participou tamén nas Mocedades Galeguistas, e asistiu á Asemblea organizada en Ourense en maio de 1936, de cuxa Mesa formou parte, segundo se pode comprobar en Arximiro Rojo, As Mocedades Galeguistas (Vigo: Galaxia, 1987), 74.
} 
el clima de sometimiento y estigmatización de los vencidos."80 Por máis que non fixen un seguimento sistemático, foron relativamente numerosos os mestres coruñeses aos que se demandaron este tipo de responsabilidades, segundo se pode ler nas páxinas do boletín oficial provincial, ${ }^{81}$ e o mesmo acontece na provincia de Pontevedra. ${ }^{82}$

Un deles foi Horario Fernández Gómez, que tiña ao seu cargo a escola de Caranza (Serantes) desde 1928 e non resultara sancionado na primeira fase do proceso de depuración. Na segunda fase formuláronse dous cargos na súa contra: militar no Partido Galeguista e intervir nun mitin do mesmo signo celebrado uns días antes das eleccións de febreiro de 1936 en San Xoán de Filgueira. ${ }^{83}$

A opinión que merecía por parte das autoridades locais en materia profesional era boa, e o depurado achegaba informes que así o confirmaban, como o do inspector Luis Jorge de Pando -datado en 1939-, segundo o cal en Caranza había "una verdadera Escuela y un verdadero apostol de la enseñanza al frente de ella". Tamén coincidían os informantes na súa pertenza ao $\mathrm{PG}$, aínda que o pai de familia era menos contundente, e limitábase a afirmar que algunha persoa, se cadra mal informada, "susurró" que "tenía sus simpatías por la Región o sea por el partido Galleguista”, mais a el non lle constaba. A Garda Civil engadía que estivera moi relacionado co tamén mestre Juan Ramón García Niebla, cuxas ideas eran "muy extremistas" e que xa fora fusilado.

Horacio optou por iniciar a defensa contestando ao segundo cargo. Recoñecía que efectivamente sintonizara co ideal galeguista, especialmente desde que comprobou, ao facer o servizo militar, o desprezo co que moitos ollaban Galicia, tanto que "el nombre de gallego era sinónimo de inculto y grosero". Tal circunstancia fíxolle interesarse polo estudo da historia e a cultura da terra que o vira nacer, e mesmo impartira algunhas conferencias co propósito de difundir as achegas de Galicia á cultura universal. Unha das conferencias tivera como escenario o lugar que se sinalaba no segundo cargo, pero non se celebrara uns días antes das eleccións de febreiro, como nel se afirmaba, senón ben entrado o mes de xuño -fora o mesmo día 28, día da votación do Estatuto de Autonomía, como especifica o mestre en fase de revisión-.

\footnotetext{
80 Julio Prada Rodríguez, La España masacrada (Madrid: Alianza Editorial, 2010), 310.

${ }^{81}$ Citaremos, a modo de exemplo, os seguintes nomes (entre paréntese figura a data de publicación no BOP): Arístides Fermoso Miranda (7/11/1939), Eugenio Vidal Ojén (9/10/1940), María de Dios Silva (5/11/1940), Ramón Figueroa Vilachá (23/12/1940), José Gerardo Brea Rodríguez (3/1/1941), Francisco Calviño Salazar (11/1/1941), Baldomero Fraile Castilblanco (15/5/1941), Antonio Cristóbal de la Fuente (2/6/1941), José María Rosende Purriños (11/6/1941), Fernando Barcia Veiras (30/6/1941), Jesús Mejuto Vázquez (29/7/1941), Cecilio Rodríguez González (26/8/1941), Cipriano Villar Bretal (29/10/1941), Pedro Almazán Ramos e Manuel López González (26/9/1942).

${ }^{82}$ Véxase a relación ofrecida por Lucio Martínez Pereda en Medo político e control social na retagarda franquista (Vigo: Xerais, 2015), 384-421.

${ }^{83}$ AGA, 32/12537-39. Sempre que non se sinale outra procedencia, deberá entenderse que os datos proceden do expediente de depuración. Sobre a traxectoria deste mestre, pode lerse o traballo de José Manuel Suárez Sandomingo, "Horacio Fernández Gómez", Galicia Digital. El portal de Galicia para el mundo, 30/12/2015.
} 
En esa conferencia hablé de Galicia, de su música, de sus poetas, de la riqueza arquitectónica de nuestras catedrales y monasterios, de la belleza insuperable de nuestros campos y nuestras rías, para llegar a la conclusión de que debemos de sentirnos orgullosos de haber nacido en este pedazo de tierra española. Hablé también de la necesidad de que Galicia obtuviese el Estatuto con el fin de resolver alguno de nuestros problemas específicos y de esta manera poder mejorar la situación de nuestra tierra. Yo no sé si esto es hoy materia condenable. Lo que sí puedo afirmar es que yo creía de buena fe que el Estatuto era conveniente para nuestra región, máxime teniendo en cuenta que un hombre de tan alta mentalidad y probado patriotismo como D. José María Gil Robles la solicitaba para Castilla y el llorado patricio Don José Calvo Sotelo se había manifestado favorable a los Estatutos regionales. ${ }^{84}$

Recoñecía, así mesmo, a pertenza ao Partido Galeguista. Afiliárase nos primeiros tempos desta formación, cando estaba integrada por un fato de "románticos e ingenuos", pero manifestaba a súa total discrepancia coa orientación que se lle imprimira nos últimos anos, que o desnaturalizara ao convertelo nun partido de esquerdas. De modo que algúns optaron por constituír Dereita Galeguista, e outros, coma el mesmo, decidiron manterse á marxe da actividade política.

A Comisión tivo nesta ocasión unha actitude sorprendentemente benévola, tendo en conta a traxectoria dos depuradores coruñeses. Consideraba probada a militancia no galeguismo e a participación en actos de propaganda desa mesma natureza, polo que lle correspondería o traslado fóra de Galicia, mais tomando en consideración as "circunstancias" que concorrían no caso -o mestre non fora se cadra totalmente consciente do alcance dalgunhas das súas actuacións propagandistas-, sometía á consideración das autoridades superiores a posibilidade de que fose castigado cunha pena menor. Estas, porén, acordaron o seu trasladado fóra de Galicia durante cinco anos e a inhabilitación para o desempeño de cargos directivos e de confianza. $O$ desterro cumprirao en Cebreros del Río (León), e a sanción, aínda que recorrida, foi ratificada en $1942 .{ }^{85}$ A Comisión Superior Ditaminadora de Expedientes considerou probado que participara nun acto a prol do Estatuto de Autonomía, e declarouse incompetente para calibrar se fora ou non consciente da transcendencia de tal intervención. Sexa como for, "la cultura media que es obligado exigir a un maestro debía dotarle de elementos de juicio suficientes para el encauzamiento de su propia conducta".

Por estas datas, Horacio estaba a ser sometido a un expediente polo Tribunal Rexional de Responsabilidades Políticas da Coruña. ${ }^{86}$ Acompañábano no proceso, iniciado en 1941, Ricardo Carvalho Calero, Gonzalo Torrente Ballester, Manuel Leite Monteagudo, Manuel Martínez Monteagudo, Enrique Landrove Fernández, Domingos Pombo López, Emilio Sanjurjo García, Angel Valcarcel Piñeiro, Fiz Álvarez do Castelo, Francisco Yáñez Lorenzo, Álvaro Vizoso Garrido, Luis Cereijo Mosquera, ${ }^{87}$ Ernesto Rafales García e Rodri-

\footnotetext{
${ }^{84}$ En 1933 pronunciara en Sedes (Narón) unha conferencia sobre esta mesma temática: "Galicia ante la autonomía" (La Voz de Galicia, 17/2/1933).

${ }^{85}$ La Voz de Galicia publicou a orde que ratificaba a sanción inicial o 19 de febreiro de 1942.

${ }^{86}$ Arquivo do Reino de Galicia, caixa 184, expediente 171. A documentación citada nas páxinas que seguen procede deste expediente.

${ }^{87} \mathrm{O}$ Tribunal sobreseu 0 caso de Luis Cereijo Mosquera, debido a que xa fora xulgado por rebelión militar en Santiago e condenado a pena de morte, que lle será conmutada, e a pagar unha multa.
} 
go Rodríguez Rico. Eran acusados de exercer funcións directivas no Partido Galeguista de Ferrol, e sabemos que efectivamente oito formaban parte do Consello Direitivo elixido en febreiro de 1935, presidido por Domingos Pombo. ${ }^{88}$

A Garda Civil, a alcaldía, a policía e o párroco acusábano de formar parte do Partido Galeguista, ao que a Falange se refería como "Partido Regionalista Gallego de izquierdas". O informe policial especificaba que exercera os cargos de presidente, vicepresidente e vogal, delegado por Ferrol para asistir á IV Asemblea e delegado do periódico A Nosa Terra nesta mesma cidade. $O$ acusado aceptou os cargos que se lle apuñan, aínda que se declarou absolutamente alleo á Fronte Popular, por se dar de baixa da formación galeguista ao virar esta cara á esquerda. Tamén apelou ao apoio prestado á sublevación desde os seus primeiros momentos:

Que después de iniciado el Glorioso Alzamiento Nacional, se presentó inmediatamente a la Guardia Civil de San[ta] Marta de Ortigueira, donde se hallaba veraneando, poniéndose a disposición de las Autoridades de la Zona Nacional, para lo que hiciese falta, según también lo acredita, y por último, el compareciente es Católico práctico y [...] desempeña el cargo de Secretario de Acción Católica de San Juan de Filgueira, como lo acredita suficientemente: $Y$ que ha postulado por la Parroquia en que vive a favor del Ejército y organizó, con la Maestra, varios festivales encaminados a tal fin benéfico y patriótico.

O segundo delegado elixido en Ferrol para asistir á IV Asemblea do PG foi Ricardo Carvalho Calero, e a ambos acompañou Domingos Pombo López, na súa condición de conselleiro de sección. ${ }^{89}$ Este era un dos pasaxeiros polos que agardaba no porto de Vigo o bou Eva -ao que xa fixemos referencia- o 23 de abril de 1937. Chegou tarde á cita, polo que librou da morte. $O$ resto dos compañeiros, ao ser descuberta a tentativa de fuga, optaron por un suicidio colectivo.

Carvalho Calero debeu responder de exercer como presidente do grupo galeguista de Ferrol e de actuar como compromisario nas eleccións a presidente da República. Nas súas declaracións, efectuadas 02 de setembro de 1942, recoñeceu a pertenza ao Partido Galeguista de Ferrol, "posiblemente como socio fundador, por cuanto fue de los primeros y desempeñó el cargo de Presidente en esta ciudad", e negou que fixera propaganda esquerdista ou cometera actos contra o denominado Movemento Nacional. Transcorridas algo máis de catro décadas, lembraba estes acontecementos en resposta ás preguntas de Carmen Blanco: "Si, en Ferrol constituímos un grupo, si, había un grupo galeguista; eu mesmo fun presidente (non puden evitalo) dese grupo. Contaba con numerosos aderidos, até mesmo chegamos a publicar un periódico que se titulaba Erte!". ${ }^{90}$

Pola súa parte, Gonzalo Torrente Ballester admitiu que efectivamente fora secretario deste partido desde 1933 a 1934, pero advertía que se tratara dunha "chiquillada sin valor político". Ao se producir o "Octubre rojo", expresara a súa discrepancia coa política republicana, polo cal "fue expulsado del Partido Galleguista". En carta dirixida ao presidente

\footnotetext{
${ }^{88}$ El Pueblo Gallego, 5/2/1935.

${ }^{89}$ El Correo Gallego, 20/4/1935.

${ }^{90}$ Carmen Blanco, Conversas con Carballo Calero, 62.
} 
desta organización, "redactada en castellano" -subliñado no orixinal-, que debía andar por algures, argumentaba a súa disidencia. Polo demais, "desde 1934, militó en el Grupo Jonsista disidente de Santiago de Compostela", e así o podían acreditar os camaradas Manuel Souto Vilas e Santiago Montero Díaz. A súa traxectoria nos seguintes anos, que reproducimos in extenso por non ser moi coñecida, resúmea así:

d) Después de las elecciones de 1936 -en las que, desde luego, no tomó parte alguna, no habiendo votado por no figurar en el censo electoral- se manifestó siempre públicamente como Nacional-sindicalista; con carácter de tal hizo unas oposiciones a Auxiliar de la Universidad de Santiago contra un candidato socialista, y a consecuencia de esto fue denunciado por todos los Jefes del Frente Popular en Santiago de Compostela, así como en el diario socialista Claridad, teniendo que marchar de Ferrol por estar amenazado y no poder defenderse por inutilidad física. Por este tiempo de Frente Popular, tuvo conversaciones conspiratorias con el Capitán de Fragata Don Pablo Suances, y en unión del mismo y de otros amigos, protegió el Colegio de los Mercedarios de esta Ciudad en varias ocasiones en que se esperaba un asalto rojo, como pueden atestiguar el referido Capitán de Fragata y el rector de dicho Colegio Padre Fermín Álvarez. Debe advertir que en pleno Frente Popular daba clases diariamente en el referido Colegio, con evidente peligro de su vida. e) Al estallar el Glorioso Movimiento, se hallaba el declarante en Francia, de donde se reintegró a la Zona Nacional en cuanto tuvo medios de transporte, militando en FET y de las JONS [...] g) El declarante, antes de la guerra, mantuvo una posición frente a la Falange, no de enemistad, sino de crítica, como puede atestiguar el mencionado camarada Jesús Suevos, único con quien mantuvo conversaciones políticas con anterioridad al Alzamiento; pero esta posición crítica, se modificó a partir de 1934, evolucionando hacia el Nacional-sindicalismo hasta el punto de sumarse a los partidarios de Ramiro Ledesma Ramos; finalmente, a fines de 1935, el declarante sostenía la necesidad de unión de las dos ramas, la Falange y las JONS disidentes, y en este sentido tuvo conversaciones con muy destacados jonsistas, entre otros con el camarada Montero Díaz. ${ }^{91}$

A decisión final, adoptada pola Audiencia da Coruña en 1944, cando xa estaba extinguido o Tribunal Rexional de Responsabilidades Políticas, foi continuar o procedemento contra Rodrigo Rodríguez Rico e sobreser o resto dos casos. Os de Carvalho Calero e López Pombo por insolvencia económica -Carvalho gañaba por esas datas unhas 300 pesetas ao mes na Academia Rapariz, e conseguía algúns ingresos adicionais dando clases particulares-, circunstancia recollida no artigo $8^{\circ}$ da Lei de responsabilidades políticas reformada en 1942, e os de Fernández Gómez e Torrente Ballester en virtude dos eximentes do artigo $3 .^{\circ}$ desa mesma lei, un dos cales se refería ao arrepentimento público despois do 18 de xullo e a adhesión ao Movemento Nacional.

Outro ilustre galeguista ao que se lle demandaron responsabilidades políticas foi, como xa anticipamos, don Ramón Otero Pedrayo, a quen o tribunal da Coruña impuxo o 15 de outubro de 1941 unha multa de 10.000 pesetas, ademais de inhabilitalo para 0 desempeño de cargos públicos de mando, confianza e directivos. ${ }^{92}$

\footnotetext{
${ }^{91}$ As persoas invocadas por Torrente foron chamadas a declarar, e confirmaron, no fundamental, as declaracións deste, e especialmente a súa falta de compromiso co galeguismo. Santiago Montero Díaz advertirá, no entanto, que mal podía formar parte das JONS galegas disidentes por non existir en Galicia tal disidencia.

92 ACME, Revisión depuración, caixa 83715-4183.
} 


\section{Consideracións finais}

Os militares sublevados tiñan no punto de mira dos seus fusís a Fronte Popular, esa "funesta" coalición da que formaba parte do Partido Galeguista. Así as cousas, os nacionalista galegos, ao apostaren, en terminoloxía rebelde, por unha España rota e asemade roxa, eran particularmente propicios á represión. E efectivamente, foron relativamente numerosos os profesores que morreron, resultaron depurados ou sufriron algún outro tipo de sanción por mor das súas ideas.

O catolicismo e o conservadorismo que profesaba unha parte do galeguismo contribuíu á modulación desta represión, malia non constituír ningunha garantía de impunidade, como pon de manifesto o caso de Otero Pedrayo: só un membro da Comisión de Cultura e Ensino considerou que a súa defensa do catolicismo nas Cortes Constituíntes de 1931 permitía permutar a separación definitiva do ensino polo traslado fóra de Galicia. Andando o tempo, e unha vez que os aliados derroten o fascismo europeo, este tipo de avais adquirirán máis peso.

\section{Bibliografía}

Beramendi, Justo. De provincia a nación. Historia do galeguismo político. Vigo: Xerais, 2007.

Blanco, Carmen. Conversas con Carballo Calero. Vigo: Galaxia, 1989.

Casares, Carlos. Conciencia de Galicia. Risco, Otero e Curros. Tres biografías. Vigo: Galaxia, 2004.

Castro, Xavier. O Galeguismo na encrucillada republicana. Ourense: Servizo de Publicacións da Deputación Provincial, 1983, 2 vols.

Cid Fernández, Xosé Manuel. Educación e Ideoloxía en Ourense na II República. Santiago de Compostela: Andavira Editora, 2010.

Comoxo, Xosé e Santos, Xesús. Rianxo na súa historia. Consecuencias da Guerra Civil (1936-1939). A Coruña: Deputación Provincial da Coruña, 2010.

Costa Rico, Antón. Historia da educación e da cultura en Galicia. Vigo: Xerais, 2002.

Costa Rico, Antón. "Os ensinantes galegos no 36. Os mortos e os exiliados". N’A I/ República e a Guerra Civil (Actas do Il Congreso da Memoria), 487-521. Narón: Asociación Cultural Memoria Historia Democrática, 2006.

Costa Rico, Antón. "As escolas dos americanos: en castelán ou en galego? 'Moito mal que fan a Galicia". Revista Galega de Educación 53 (2012): 42-46.

De Gabriel, Narciso. "O proceso de depuración do maxisterio na provincia da Coruña”. Sarmiento. Revista Galego-Portuguesa de Historia da Educación 21 (2017): 119-158.

De Gabriel, Narciso. “Os mestres mortos daquel verán”. A Trabe de Ouro 108 (2018): 15-34. 
De Gabriel, Narciso. Xosé María Álvarez Blázquez, mestre republicano. Diario escolar e desterro. Vigo: Galaxia, 2019.

De Gabriel, Narciso e Sarille, Xosé Manuel. Arximiro Rico, luz dos humildes. Santiago de Compostela: Gesto Dentro Editora, 2002.

De Luis Martín, Francisco. La FETE en la Guerra Civil española (1936-1939). Barcelona: Ariel, 2002.

Diéguez Cequiel, Uxío Breogán. Álvaro de las Casas. Biografía e documentos. Vigo: Galaxia, 2003.

Ermida Meilán, Xosé Ramón. Mortos por amor á Terra. A represión sobre o nacionalismo galego (1936-1950). Santiago de Compostela: Sermos Galiza, 2016.

Fariña Busto, Francisco. Ferro Couselo. Vigo: Ir Indo, 1996.

Fernández del Riego, Francisco. O río do tempo. Unha historia vivida. Sada: Ediciós do Castro, 1990.

Fernández Santander, Carlos. Alzamiento y Guerra Civil en Galicia (1936-1939). Sada: Ediciós do Castro, 2007, 2 vols.

García Díaz, Jesús M. La depuración del magisterio nacional en la provincia de A Coruña. A Coruña: Fundación Luis Tilve, 2018.

Lamela García, Luis. 1936. La "Cruzada" en Compostela. La Guerra Civil y la represión franquista en los documentos policiales y militares. Sada: Edicións do Castro, 2005.

Llorca Freire, Guillermo. "Juan García Niebla. A Pedagoxía ó servicio do cidadán". Idea. Intercambio de experiencias de aula 6 (2006): 106-109.

Marco López, Aurora e Porto Ucha, Anxo Serafín. A Escola Normal de Santiago de Compostela. De Escola Normal Superior a Escola Universitaria (1849-1996). Santiago: USC, 2000.

Martínez Pereda, Lucio. "La depuración franquista del Instituto de Vigo: una primera aproximación". Boletín do Instituto de Estudios Vigueses 14 (2008/2009): 183-208.

Martínez Pereda, Lucio. Medo político e control social na retagarda franquista. Vigo: Xerais, 2015.

Negrín Fajardo, Olegario. "La depuración franquista del profesorado en los institutos de segunda enseñanza de España (1937-1943). Estudio cuantitativo para Galicia". Sarmiento. Anuario Galego de Historia da Educación 10 (2006): 59-99.

Peña Saavedra, Vicente. Éxodo, organización comunitaria e intervención escolar. La impronta educativa de la emigración transoceánica en Galicia. Santiago de Compostela: Xunta de Galicia, 1991, 2 vols. 
Portas Ferro, Xesús e A. Campaña, Gumersindo. “Xesús Ferro Couselo: Un home do pobo para o pobo". Encrucillada. Revista Galega de Pensamento Cristián 97 (1996): 120-138.

Porto Ucha, Anxo Serafín. Mestras e mestres pontevedreses depurados polo franquismo. Primeiras acción represivas e estudo por concellos no sur da provincia (19361942). Ponteareas: Edicións Alén Miño, 2008.

Prada Rodríguez, Julio. La España masacrada. Madrid: Alianza Editorial, 2010.

Reverte, Jorge M. La Batalla de Madrid. Barcelona: Crítica, 2004.

Rodríguez Fer, Claudio. A literatura galega durante a Guerra Civil (1936-1939). Vigo: Xerais, 1994.

Rojo, Arximiro. As Mocedades Galeguistas. Vigo: Galaxia, 1987.

Romero Masiá, Ana. María Barbeito. Unha vida ao servizo da escola e dos escolares (1880-1970). A Coruña: Baía Edicións, 2014.

Santalla López, Andrés. "Rafael Fernández Casas". Idea. Intercambio de Experiencias de Aula 7 (2001): 83-85.

Senén, Felipe e Díaz Martínez, Carlos. Xesús Ferro Couselo. A búsqueda da identidade e o encontro cos devanceiros. A Coruña: Espiral Maior, 1996.

Sobrino Ceballos, Juan e Domínguez Ferro, Manuel. "¡Que pouco vale unha mestra!' Un achegamento á figura de María Vázquez Suárez". Cátedra. Revista eumesa de estudios 18 (2011): 209-227.

Suárez Sandomingo, José Manuel. "Rafael Fernández Casas, un maestro laico e innovador". Galicia Digital. El portal de Galicia para el mundo (11/9/2012).

Suárez Sandomingo, José Manuel. "Horacio Fernández Gómez". Galicia Digital. El portal de Galicia para el mundo (30/12/2015).

Válcárcel, Marcos. Xesús Ferro Couselo. Unha fotobiografía (1906-1975). Vigo: Xerais, 1996.

Valín Fernández, Alberto. "Política, apoio mutuo e República: A masonería provincial coruñesa durante a Segunda República". N'A II República e a Guerra Civil (Actas do II Congreso da Memoria), 39-63. Narón: Asociación Cultural Memoria Histórica Democrática, 2006. 